\title{
KEMAMPUAN DECISION MAKING SISWA SMA DALAM PEMBELAJARAN FISIKA BERBASIS INKUIRI TERBIMBING
}

\author{
${ }^{1)}$ Alivea Pisca Dianty, ${ }^{1}$ Supeno, ${ }^{1)}$ Sri Astutik \\ ${ }^{1)}$ Program Studi Pendidikan Fisika FKIP Universitas Jember \\ Email: aliveapiscadianty@gmail.com
}

\begin{abstract}
Students must be able to make decisions effectively in urgent conditions and be able to formulate strategies to take action in an effort to make the situation under control. During learning at school, there are still many students who tend to be more receptive to information than to provide solutions that can solve the problems. The ability to make decisions can be trained using the guided inquiry learning model, because the essence of the guided inquiry strategy is relate to the decision making skills. The use of guided inquiry models in learning can increase student to think critically, be more productive, be more skilled in obtaining information and making decisions. The research aims is to know the ability to take the decision making of students high school in learning physics based on guided inquiry. This type of research was descriptive research. This research is used to describe the participation of high school students in making decision on guided inquiry on physics learning. The results obtained by the study of guided inquiry learning models can increase student participation in making decisions.
\end{abstract}

Keywords: guided inquiry, decision making, physics learning.

\section{PENDAHULUAN}

Perkembangan dunia di abad 21 saat ini sangat pesat di semua aspek kehidupan, mulai dari aspek sosial, keilmuan, sumber daya manusia, dan globalisasi. Semua aspek tersebut menuntut seorang pendidik agar melaksanakan proses belajar yang sesuai dengan kondisi abad 21. Seorang pendidik harus mampu mengantarkan peserta didik ke arah yang lebih baik guna mempersiapkan diri menghadapi permasalahan seiring dengan perkembangan teknologi, bahkan dalam persaingan di dunia kerja. Demikian pula dalam hal pembelajaran, dimana ilmu sains sangat berkaitan dengan perkembangan abad 21, salah satunya adalah ilmu fisika. Dalam pembelajaran fisika, siswa didorong untuk belajar aktif, berpikir kritis, dan berpikir tingkat tinggi dalam menyelesaikan suatu permasalahan (Pratiwi dan Nurhidayati, 2017). Siswa yang memiliki kemampuan untuk menghubungkan berbagai konsep, menafsirkan, memecahkan masalah, berkomunikasi, bernalar, dan membuat keputusan yang tepat dapat diartikan bahwa siswa tersebut memiliki keterampilan tingkat tinggi (Astutik dan Prahani, 2018).

Menurut Dewi dan Riandi (2015), berpikir kompleks merupakan kemampuan berpikir yang sesuai dengan abad 21 yang didasarkan pada proses berpikir dasar. Setidaknya terdapat ada empat proses berpikir kompleks yang terjadi pada seseorang, salah satunya yaitu pengambilan keputusan (decision making). Tujuan pembelajaran fisika bukan hanya 
mengarahkan siswa untuk memperoleh pengetahuan saja, tetapi juga dilatih untuk mampu memecahkan suatu permasalahan (Fitriyani, Supeno, dan Maryani, 2019). Kesejahteraan, hubungan, dan kesuksesan siswa di masa yang akan datang sangat berpengaruh terhadap keputusan yang diambil oleh siswa. Pemecahan masalah tidak hanya sekedar menekankan pada analisis terhadap aspek kuantitatif, seperti prosedural dalam matematika tetapi juga harus menekankan pada analisis aspek kualitatif. Hal ini dapat berupa pemilihan prinsip dan konsep yang tepat dalam menyelesaikan masalah (Trisayuni, Supeno, dan Sudarti. 2018).

Pembelajaran fisika pada dasarnya mengajarkan siswa bagaimana membuat suatu keputusan yang tepat berdasarkan pengetahuan dan proses ilmiah yang sistematis (Hutapea dan Simanjuntak, 2017). Faktanya, pembelajaran fisika selama ini kurang memaksimalkan kemampuan siswa untuk berpikir ilmiah (Supeno, Astutik, Bektiarso, Lesmono, dan Nuraini, 2018). Pembelajaran saat ini bersifat teacher center learning, sehingga kemampuan kognitif, afektif, dan psikomotorik peserta didik kurang seimbang (Nasihah, Supeno, dan Lesmono, 2018).

Bekerja dalam tim dapat meningkatkan efisiensi siswa dalam mengambil keputusan daripada bekerja secara individu. Hal ini dapat dilihat berdasarkan adanya kenaikan skor dari -3 menjadi 4 pada hasil studi PISA tahun 2015 (OECD, 2018). Soenarko, Andayani, dan Junaidi (2018) menyatakan bahwa berdasarkan penelitian sebelumnya, sebagian besar peserta didik baik dalam menghapal materi pelajaran namun peserta didik tidak memahaminya. Banyak siswa juga belum bisa mengaitkan antara materi dengan pemanfaatan materi tersebut dalam kehidupan sehari-hari. Hal ini menunjukkan bahwa belum dilatihnya keterampilan pengambilan keputusan dengan baik. Jika ditinjau dari proses pembelajaran, guru lebih banyak mengunakan metode ceramah dalam mentransfer materi dan juga banyak memberikan informasi yang diperlukan peserta didik untuk belajar sehingga siswa cenderung kurang memahami materi yang diajarkan.

Mustofa dan Rusdiana (2016) menyatakan bahwa selama pembelajaran di sekolah masih banyak siswa yang belum mampu memahami masalah yang diberikan oleh guru. Jika siswa mengalami kesulitan dalam memahami suatu masalah, siswa juga akan mengalami kesulitan dalam membuat rencana solusi untuk menyelesaikannya. Ketika siswa mengalami kesulitan dalam merencanakan solusi, tentu dapat berdampak terhadap ketepatan solusi yang diberikan. Belajar membuat keputusan secara efektif dalam kondisi mendesak dan tidak pasti tidak mudah dicapai dalam pengaturan kelas menggunakan pembelajaran konvensional dengan metode ceramah (Hutapea dan Lubis, 2017). Proses belajar yang mampu meningkatkan keterampilan berpikir seperti keterampilan mengambil keputusan dapat terjadi salah satunya jika guru dapat merancang kegiatan belajar yang dapat membantu dan membimbing siswa untuk mencapai kompetensi yang telah ditetapkan (Ischinger, 2009). 
Model inkuiri terbimbing merupakan model pembelajaran yang dalam implementasinya menuntut partisipasi aktif siswa dalam penyelidikan ilmiah. Dengan kata lain, inkuiri terbimbing adalah perluasan proses penemuan yang digunakan lebih mendalam dan lebih tinggi tingkatannya, misal merumuskan masalah, merancang eksperimen, melakukan eksperimen, mengumpulkan data, menganalis data, dan menarik kesimpulan (Arends, 2014; Joyce, Weil, dan Calhoun, 2014; Kilbane dan Milman, 2014). Esensi inkuiri merupakan suatu proses penemuan ilmiah, sedangkan pengambilan keputusan harus didasarkan pada sejumlah data yang diperoleh melalui proses penemuan ilmiah. Dengan kata lain, strategi inkuiri terbimbing ini merupakan suatu rangkaian kegiatan belajar yang melibatkan secara maksimal seluruh kemampuan siswa untuk mencari dan menyelidiki secara sistematis, kritis, logis, dan analitis sehingga mereka dapat menemukan sendiri pengetahuannya dengan penuh percaya diri (Maryani, 2018).

Model pembelajaran inkuiri terbimbing dengan kemampuan decision making sangat berhubungan erat, sehingga inkuiri terbimbing diprediksi dapat berpengaruh terhadap kemampuan decision making fisika siswa. Joyce, Weil, dan Calhoun (2014) mengatakan bahwa pemahaman sains, berpikir kritis, lebih produktif, dan siswa menjadi lebih terampil dalam memperoleh informasi dan membuat keputusan dapat ditingkatkan dengan model pembelajaran inkuiri. Oleh karena itu, berdasarkan penjelasan tersebut menjadi alasan dalam melakukan penelitian tentang partisipasi siswa SMA pada pembelajaran fisika berbasis inkuiri terbimbing untuk mengkontruksikan keputusan sains secara tepat.

\section{METODE PENELITIAN}

Jenis penelitian ini adalah penelitian deskriptif. Penelitian ini bertujuan untuk mendeskripsikan partisipasi siswa SMA pada pembelajaran fisika yang berbasis inkuiri terbimbing untuk mengkontruksikan decision making pada materi fluida statis. Penelitian ini dilaksanakan di SMAN Ambulu pada kelas XI IPA. Penentuan sampel penelitian menggunakan teknik purposive sampling area, yaitu penentuan sampel dengan mempertimbangkan suatu hal tertentu (Sugiyono, 2013).

Pembelajaran dilakukan selama tiga pertemuan dengan durasi waktu setiap pertemuan $2 \times 45$ menit. Pada pertemuan pertama, guru memberikan materi tentang tekanan hidrostatis. Hukum Pascal merupakan materi yang diberikan guru pada pertemuan kedua. Pertemuan terakhir yaitu ketiga, guru memberikan materi tentang hukum Archimedes. Langkah pembelajaran diawali dengan siswa diberikan masalah dan alternatif jawaban berdasarkan masalah yang diberikan guru. Siswa menuliskan jawaban sementara berdasarkan alternatif jawaban yang diberikan, selanjutnya siswa melakukan tahapan inkuiri yang terdapat serangkaian percobaan. Data hasil percobaan dianalisis oleh siswa sebagai data pendukung dalam mengambil keputusan. Siswa dapat berlatih mengambil keputusan siswa 
dengan menggunakan Lembar Kerja Peserta Didik (LKPD) yang di dalamnya terdapat beberapa indikator dalam mengambil keputusan.

Teknik pengumpulan data untuk mengetahui kemampuan siswa dalam mengambil keputusan diperoleh berdasarkan observasi dan isian siswa pada LKPD. Data dari observasi berupa data kualitatif dan kuantitatif. Data kualitatif merupakan data yang didapatkan saat siswa menyampaikan jawaban dan mengarah pada indikator mengambil keputusan. Data kuantitatif merupakan data yang didapat berdasarkan jumlah siswa yang menyampaikan jawaban tiap indikator mengambil keputusan dengan benar. Data isian siswa pada LKPD merupakan data kuantitatif yang dianalisis berdasarkan jumlah siswa yang memberikan jawaban dan kriteria jawaban yang diberikan. Indikator mengambil keputusan yang digunakan meliputi kemampuan dalam memberikan hipotesis berdasarkan alternatif jawaban, mentabulasi data hasil percobaan, mengevaluasi alternatif jawaban, dan mengambil keputusan.

Data yang diperoleh dianalisis berdasarkan indikator dalam mengambil keputusan. Kemampuan mengambil keputusan pada saat siswa mengajukan hipotesis, mengumpulkan data, dan menarik kesimpulan dikelompokkan berdasarkan jumlah siswa yang mengajukan hipotesis dengan tepat dan tidak tepat. Penarikan kesimpulan dilakukan siswa dengan membandingkan data hasil percobaan dengan alternatif jawaban sesuai dengan permasalahan yang diberikan.

\section{HASIL DAN PEMBAHASAN}

Pembelajaran inkuiri terbimbing adalah kegiatan pembelajaran yang menekankan pada proses berpikir secara kritis dan analitis untuk mencari dan menemukan sendiri jawaban dari pertanyaan yang diajukan. Proses berpikir dapat tercipta melalui kegiatan tanya jawab antara guru dan siswa. Kegiatan tanya jawab bisa melibatkan proses berpikir karena adanya stimulus dari guru kepada siswa yang melibatkan interaksi antar individu, saling tukar pengalaman, informasi, dan memecahkan masalah (Sanjaya, 2008). Dengan demikian dapat dikatakan bahwa pembelajaran inkuiri terbimbing diharapkan dapat meningkatkan partisipasi siswa SMA pada pembelajaran fisika untuk mengkontruksikan keputusan sains secara tepat.

Penelitian ini dilakukan selama tiga pertemuan pembelajaran. Materi pada masing-masing pertemuan adalah tentang tekanan hidrostatis untuk pertemuan pertama, tekanan hidrostatis pertemuan kedua, dan hukum Archimedes untuk pertemuan ketiga. Pembelajaran diawali dengan siswa diberi masalah dan alternatif jawaban. Selanjutnya siswa melakukan tahapan inkuiri disertai percobaan untuk mendorong mereka dalam memilih alternatif jawaban untuk mengambil keputusan.

Pada pembelajaran pertemuan pertama, guru memberikan materi tekanan hidrostatis. Langkah pembelajaran diawali dengan pengajuan masalah dan alternatif jawaban kepada siswa. Pada tahap ini, guru memberikan penjelasan singkat kepada siswa tentang materi yang akan dipelajari kemudian membagi menjadi kelompok-kelompok kecil dan 
memberikan permasalahan mengenai fenomena fisika tentang tekanan hidrostatis. Siswa dituntut untuk berpikir secara aktif dan kreatif untuk memahami fenomena yang diberikan oleh guru. Permasalahan fisika yang diajukan pada siswa berupa peletakan kantong infus yang sesuai agar cairan infus dapat memasuki pembuluh darah dengan baik, sedangkan alternatif jawabannya yaitu peletakan kantong infus di atas tubuh pasien, sejajar dengan tubuh pasien dan di bawah tubuh pasien.

Siswa dibimbing untuk menuliskan hipotesis jawaban ketika siswa sudah memahami permasalahan yang diberikan. Sebagai jawaban sementara, hipotesis perlu diuji kebenarannya. Perkiraan hipotesis bukan sembarang perkiraan, tetapi harus memiliki landasan berpikir yang kokoh agar hipotesis yang dimunculkan dapat bersifat rasional dan logis. Sebanyak 35 siswa dapat mengajukan hipotesis dengan benar pada pertemuan pertama.

Kegiatan siswa selanjutnya adalah melakukan inkuiri melalui serangkaian percobaan. Percobaan yang diberikan oleh guru selaras dengan permasalahan yang diberikan, sehingga siswa dapat menghubungkan fakta dengan alternatif jawaban yang tersedia. Pada tahap ini, siswa menyajikan hasil percobaan yang telah dilakukan ke dalam kolom yang telah disediakan pada LKPD. Serangkaian kegiatan siswa dalam mengumpulkan data berguna untuk mendukung pengambilan keputusan yang diberikan guru pada materi tekanan hidrotatis. 35 siswa pada pertemuan pertama memperolah data hasil percobaan yang sesuai dengan teori. Alokasi waktu untuk kegiatan mengumpulkan data yang direncanakan pada pertemuan pertama selama 20 menit, namun dalam riil pelaksanaanya membutuhkan waktu selama 30 menit. Hal ini disebabkan karena kurang efisien waktu yang digunakan siswa dan ada beberapa siswa yang lama dalam melakukan percobaan, sehingga waktu untuk mengumpulkan data mengalami hambatan. Hal ini juga disebabkan karena siswa belum terbiasa dengan kegiatan inkuiri yang menuntut siswa untuk melakukan dengan cepat dan tepat agar kegiatan inkuiri dapat berlangsung dengan baik. Langkah selanjutnya adalah menarik kesimpulan. Siswa dituntut untuk menarik kesimpulan berdasarkan permasalahan menggunakan data-data pendukung lalu mengkaitkannya dengan hipotesis awal yang telah dibuat. Alokasi waktu yang direncanakan saat menarik kesimpulan pada pertemuan pertama selama 10 menit. Namun keadaan sebenarnya memerlukan waktu 5 menit. Hal ini disebabkan karena kurang efisiennya siswa dalam mengatur waktu pada sintaks sebelumnya sehingga siswa hanya memiliki waktu sedikit dalam menarik kesimpulan. Kemampuan mengambil keputusan pada pertemuan pertama cukup baik. Hal ini dapat terlihat dari jumlah siswa yang menuliskan jawaban pada LKPD dengan benar sebanyak 35 siswa.

Hukum Pascal merupakan materi yang diberikan guru pada pertemuan kedua. Langkah pembelajaran diawali dengan pengajuan masalah dan alternatif jawaban oleh guru kepada siswa. Permasalahan yang diajukan berupa pemilihan dongkrak yang tepat untuk mobil Adi dan Budi yang keduanya memiliki berat berbeda. Guru juga memberikan dua alternatif 
dongkrak dengan spesifikasi yang berbeda. Setelah siswa memahami permasalahan yang diberikan, siswa dibimbing untuk merumuskan hipotesis jawaban. Berdasarkan permasalahan yang telah disebutkan, siswa yang mengajukan hipotesis dengan benar sejumlah 12 siswa dan 23 siswa lainnya mengajukan hipotesis salah.

Kegiatan selanjutnya yaitu siswa melakukan kegiatan inkuiri melalui serangkaian percobaan. Siswa dituntut untuk melakukan percobaan dan menuliskan hasil percobaan ke dalam lembar kerja yang telah disediakan. Aktivitas ini diharapkan dapat melatih keterampilan siswa dalam mentabulasi data hasil percobaan. Sebanyak 35 siswa memperoleh data hasil percobaan sesuai dengan teori. Alokasi waktu yang direncanakan pada pertemuan kedua yaitu 20 menit dan waktu yang digunakan 25 menit. Hal ini disebabkan karena beberapa siswa membutuhkan waktu yang lebih lama dalam melakukan percobaan.

Aktivitas selanjutnya adalah mengambil keputusan. Siswa yang mengambil keputusan dengan benar sebayak 35 siswa. Hal ini menunjukkan bahwa siswa dapat mengambil keputusan dengan baik pada pertemuan kedua. Alokasi waktu yang direncanakan pada sesi mengambil kesimpulan pada pertemuan kedua adalah selama 10 menit. Sedangkan alokasi waktu yang digunakan sesungguhnya adalah 10 menit. Hal ini menunjukkan bahwa alokasi waktu yang direncanakan sesuai dengan yang digunakan. Siswa sudah mulai paham dengan kegiatan pembelajaran berbasis inkuiri terbimbing, sehingga waktu yang digunakan tidak terlalu lama seperti pada pertemuan pertama.

Hukum Archimedes merupakan materi yang diberikan oleh guru pada pertemuan ketiga. Pembelajaran diawali dengan pengajuan masalah dan alternatif jawaban oleh guru kepada siswa. Siswa diberikan permasalahan mengenai seorang turis yang ingin merasakan mengapung di pantai. Guru memberikan tiga alternatif pantai dengan kadar air garam yang berbeda. Pantai A memiliki kadar garam 3\%, pantai B memiliki kadar garam $11 \%$, dan pantai C memiliki kadar $33 \%$. Setelah siswa memahami permasalahan yang diberikan, siswa dibimbing untuk merumuskan hipotesis jawaban. 35 siswa mampu mengajukan hipotesis dengan benar pada pertemuan ketiga.

Langkah selanjutnya yaitu siswa melakukan kegiatan inkuiri yang terdapat serangkaian percobaan. Hasil percobaan yang didapatkan siswa ditulis dalam tabel yang telah disediakan oleh guru dalam LKPD. 35 siswa mendapatkan hasil percobaan sesuai dengan teori. Alokasi waktu yang direncanakan saat melakukan kegiatan inkuiri pada pertemuan ketiga yaitu 20 menit. Waktu yang digunakan sebenarnya saat melakukan kegiatan inkuiri pada pertemuan ketiga sama seperti yang direncanakan, yaitu 20 menit. Dapat diketahui bahwa alokasi waktu yang direncanakan sesuai dengan yang digunakan.

Langkah selanjutnya yaitu siswa mengambil keputusan berdasarkan permasalahan yang diberikan. 35 siswa mampu mengambil keputusan dengan benar pada pertemuan ketiga. Alokasi waktu yang direncanakan saat siswa mengambil keputusan pada pertemuan ketiga selama 10 menit. Sedangkan 
alokasi waktu yang digunakan sesungguhnya adalah 10 menit. Hal ini menunjukkan bahwa alokasi waktu yang direncanakan sesuai dengan yang digunakan.

Kegiatan inkuiri pada pertemuan ketiga sangat baik. Siswa memiliki landasan pemikiran yang baik dalam mengajukan jawaban sementara berdasarkan alternatif jawaban yang tersedia. Siswa mampu melakukan percobaan dengan cepat dan tepat sehingga alokasi waktu yang direncanakan dapat sesuai. Siswa juga dapat mengkaitkan hasil percobaan dengan permasalahan dengan sangat baik sehingga sangat mendukung siswa dalam mengambil keputusan.

Pengelompokan jumlah siswa yang menyampaikan jawaban tiap indikator mengambil keputusan selama tiga pertemuan dapat diperinci sebagaimana ditunjukkan pada Tabel 1 .

Tabel 1. Kemampuan siswa mengambil keputusan selama 3 pertemuan pembelajaran.

\begin{tabular}{ccccccc}
\hline \multirow{2}{*}{$\begin{array}{c}\text { Pertemuan } \\
\text { Ke- }\end{array}$} & \multicolumn{6}{c}{ Jumlah siswa Untuk Setiap Kemampuan } \\
\cline { 2 - 7 } & Mengajukan Hipotesis & Mengumpulkan Data & Menarik Kesimpulan \\
\cline { 2 - 7 } & 5 & 0 & 5 & 0 & 5 & 0 \\
\hline 1 & 2 & 3 & 5 & 0 & 5 & 0 \\
\hline 2 & 5 & 0 & 5 & 0 & 5 & 0 \\
\hline 3 & & & & & & Kurang \\
\hline
\end{tabular}

Berdasarkan tabel 1, dapat dilihat bahwa pada pertemuan pertama 5 siswa mengajukan hipotesis dengan tepat, 5 siswa mengumpulkan data sesuai dengan teori, dan 5 siswa menyampaikan kesimpulan berdasarkan permasalahan sesuai dengan materi tekanan hidrostatis dengan benar.

Pertemuan kedua menunjukkan 2 siswa mengajukan hipotesis dengan tepat, 3 siswa mengajukan hipotesis tidak tepat, 5 siswa memperoleh data percobaan sesuai dengan teori, dan 5 siswa menyampaikan kesimpulan berdasarkan permasalahan hukum pascal dengan benar. Data siswa yang mengajukan hipotesis pada pertemuan kedua terjadi penurunan. Hal ini disebabkan bahwa kurangnya pemahaman siswa pada permasalahan yang diberikan dan materi hukum pascal. Setelah siswa mekakukan percobaan dengan arahan dari guru, siswa mampu mengambil keputusan dengan benar. Hal ini dikarenakan percobaan dapat mendukung pengambilan keputusan yang dilakukan siswa.

Pertemuan ketiga menunjukkan 5 siswa mengajukan hipotesis dengan benar, 5 siswa mendapatkan data percobaan sesuai dengan teori, dan 5 siswa menyampaikan kesimpulan sesuai dengan materi hukum archimedes dengan benar. Data pada pertemuan ketiga mengalami kenaikan. Hal ini disebabkan karena materi dan permasalahan hukum Archimedes lebih mudah. Selain itu, siswa juga sudah terbiasa dengan pembelajaran berbasis inkuiri terbimbing. Siswa dapat melakukan setiap langkah pembelajaran dengan cepat dan tepat, sehingga alokasi waktu yang digunakan sesuai dengan yang direncanakan.

Penggunakan model pembelajaran inkuiri terbimbing dapat mengembangkan aspek kognitif, 
afektif dan psikomotor secara seimbang, sehingga pembelajaran melalui strategi ini dapat lebih bermakna. Guru juga dapat memberikan ruang kepada siswa untuk belajar sesuai dengan gaya belajar masing-masing siswa. Model ini juga dianggap sesuai dengan pengembangan psikologi belajar modern yang menganggap belajar adalah suatu proses perubahan tingkah laku karena adanya pengelaman yang berbeda (Sanjaya, 2008).

Model pembelajaran inkuiri terbimbing dapat lebih membiasakan siswa untuk membuktikan suatu materi pelajaran, membuktikan dengan melakukan penyelidikan sendiri oleh siswa yang dibimbing oleh guru (Simbolon dan Sahyar, 2015). Oleh karena itu, sintaks dalam pembelajaran inkuiri terbimbing yang telah dilakukan dapat mengembangkan partisipasi siswa dalam mengambil keputusan.

\section{SIMPULAN DAN SARAN}

Partisipasi siswa pada setiap pertemuan cukup baik. Adanya tanya jawab menuntut siswa untuk berpikir karena adanya stimulus yang diberikan guru. Jawaban yang disampaikan siswa pada setiap tahap beraneka ragam tentunya dengan kualitas yang berbeda pula. Kualitas jawaban siswa dapat dilihat berdasarkan kesesuaian jawaban yang disampaikan. Adanya penurunan kualitas hipotesis yang disampaikan siswa pada pertemuan kedua dikarenakan sulitnya materi dan permasalahan yang diberikan pada materi kedua.

\begin{tabular}{lcr}
\multicolumn{2}{c}{ Berdasarkan hasil dan } \\
pembahasan penelitian dapat \\
disimpulkan bahwa model \\
pembelajaran inkuiri terbimbing yang
\end{tabular}

terdiri dari tahap menghadirkan perhatian, mengorientasikan siswa pada masalah, mengajukan hipotesis, membimbing siswa dalam mengumpulkan data dan menguji hipotesis, membuat keputusan, dan mengevaluasi proses berdasarkan data yang diperoleh dari obervasi dan isian pada LKPD dalam pembelajaran didapatkan bahwa model pembelajaran inkuiri terbimbing dapat meningkatkan partisipasi siswa dalam membuat keputusan.

Adapun saran dalam penelitian ini yaitu diharapkan dapat dijadikan landasan untuk penelitian yang lebih lanjut. Selain itu, dapat dijadikan guru sebagai referensi dalam menggunakan model pembelajaran inkuiri terbimbing dalam upaya meningkatkan kemampuan siswa dalam mengambil keputusan.

\section{DAFTAR PUSTAKA}

Arends, R. I. 2014. Learning to Teach; 10th Edition. New York: McGraw-Hill Companies, Inc.

Astutik, S. dan B. K. Prahani. 2018. The practicality and effectiveness of collaborative creativity learning (CCL) model by using PhET simulation to increase students' scientific creativity. International Journal of Instruction. Vol.11,

Dewi N., dan Riandi. 2015. Analisis kemampuan berpikir sains siswa SMP kelas VII di kota Sukabumi melalui pembelajaran berbasis masalah pada tema pemanasan global. Prosiding Seminar Nasional Fisika. Vol. 4 
Fitriyani, R. V., Supeno, S., dan Maryani, M. 2019. Pengaruh LKS kolaboratif pada model pembelajaran berbasis masalah terhadap keterampilan pemecahan masalah fisika siswa SMA. Berkala Ilmiah Pendidikan Fisika, 7(2), 71-81.

Hutapea, J. dan P. M. Simanjuntak. 2017. Pengaruh model pembelajaran project based learning (PjBL) terhadap hasil belajar siswa SMA. Jurnal Inovasi Pembelajaran Fisika, 5(1), 48-55.

Hutapea, J. dan S. S. Lubis. 2017. Desain pembelajaran fisika: mengembangkan keterampilan decision making menggunakan model project based learning. Prosiding Seminar Hilirisasi.

Ischinger, B. 2009. Creating Effective Teaching and Learning Environments First Result $s$ from TALIS. OECD

Joyce, Weil, M., dan Calhoun, E. 2014. Models of Teaching, $9^{\text {th }}$ Edition. Boston: Pearson Education.

Kilbane, C. R. dan Milman, N. B. 2014. Teaching Models; Designing Instruction for $21^{\text {st }}$ Century Learners. Boston: Pearson Education.

Maryani. 2018. Pengaruh LKS dengan strategi inkuiri terbimbing berbasis penalaran terhadap keterampilan pengambilan keputusan siswa SMA pada materi energi terbarukan. Jurnal
Pembelajaran Fisika. Vol. 7(9399).

Mustofa, M. H. dan D. Rusdiana. 2016. Profil Kemampuan Pemecahan Masalah Siswa pada Pembelajaran Gerak Lurus. Jurnal Penelitian dan Pengembangan Pendidikan Fisika. Vol. 2

Nasihah, E. D., Supeno, dan A. D. Lesmono. 2018. Model problem based learning (PBL) disertai tutor sebaya untuk meningkatkan keterampilan berpikir kritis siswa SMA. FKIP E-Proceeding, 3(2)

OECD. 2018. PISA 2015 Result in Focus. OECD

Pratiwi, U. dan N. Nurhidayati. 2017. Korelasi implementasi model POE berbasis inquirihumanistik dengan higher order thinking skill level i decision making pada praktikum fisika dasar. Jurnal Eksakta Pendidikan. Vol.1

Sanjaya, W. 2008. Perencanaan dan Desain Sistem Pembelajaran. Jakarta: Kencana Prenada Media Group

Simbolon, D. H. dan Sahyar. 2015. Pengaruh model pembelajaran inkuiri terbimbing terhadap eksperimen riil dan laboratorium visual terhadap hasil belajar fisika siswa. Jurnal Pendidikan dan Kebudayaan.21(3)

Soenarko, I. G. K., Y. Andayani, dan E. Junaidi. 2018. Keterampilan 
pengambilan keputusan dan hasil belajar kimia siswa di SMA/MA Negeri Mataram ditinjau dari penerapan metode pembelajaran. Jurnal Pijar MIPA. Vol. 13, 86-89

Sugiyono. 2013. Metode Penelitian Manajemen. Bandung : CV. Alfabeta.

Supeno, S. Astutik, S. Bektiarso, A.D. Lesmono, dan L. Nuraini. 2018. What can students show about higher order thinking skills in physics learning. IOP Conf. Series: Earth and Environtmental Science.
Trisayuni, D. N. R. W., Supeno, dan Sudarti. 2018. Identifikasi kemampuan pemecahan masalah pada materi hukum newton ditinjau dari kemampuan multirepresentasi. FKIP EProceeding, 3(2) 